\title{
Influence of salinity and cadmium on capsule strength in Pacific herring eggs"
}

\author{
D. F. Alderdice ${ }^{1}$, H. Rosenthal ${ }^{2} \&$ F. P. J. Velsen ${ }^{1}$ \\ ${ }^{1}$ Department of Fisheries and the Environment, Fisheries and Marine Service, \\ Resource Services Branch, Pacific Biological Station; \\ Nanaimo, British Columbia V9R SK6, Canada, \\ and \\ ${ }^{2}$ Biologische Anstalt Helgoland (Zentrale); \\ Palmaille 9, D-2000 Hamburg 50, Federal Republic of Germany
}

\begin{abstract}
Eggs of Pacific herring (Clupea pallasi) were incubated at $5^{\circ} \mathrm{C}$ in salinities of 5,20 , and $35 \%$, and in cadmium concentrations of $0.05,0.1,1,5$, and $10 \mathrm{ppm}(20 \% \mathrm{~S})$. Bursting pressures of eggs in the eight groups were measured throughout incubation. In general, bursting pressures rose to a primary maximum after fertilization, declined, rose to a secondary maximum, then declined again toward hatching. Rate of attainment of the primary maximum was related to salinity of the incubation medium. Bursting pressures at the primary and secondary maxima reached final values of about 1300 and $700 \mathrm{~g}$, respectively, in incubation salinities at and above $20 \%$. Corresponding egg volumes were greatest in low salinities $(5 \%$ ) and near minimum values in salinities of $20 \%$ or greater $(35 \%$ ). Cadmium in the incubation medium delayed attainment of primary maximum bursting pressures and primary and secondary maxima were reduced to 200-350 g at Cd concentrations near $1 \mathrm{ppm}$. Egg volumes also decreased with increased $\mathrm{Cd}$ concentration. It appears that $\mathrm{Ca}++/ \mathrm{Cd}++$ ratios, depending on salinity and $\mathrm{Cd}$ levels in the incubation medium, influence the properties of both the jelly coat and the capsule of herring eggs. Changes in the properties of these layers could make the eggs more susceptible to mechanical damage, particularly at combinations of higher $(>1 \mathrm{ppm})$ Cd concentration and lower $(<20 \%$ ) salinities.
\end{abstract}

\section{INTRODUCTION}

During a larger investigation of the influence of salinity and cadmium on the development of Pacific herring (Clupea pallasi) eggs, effects of these factors on the strength of the outer covering of the herring egg were examined. The non-specific terms "jelly coat" and "capsule" (zona radiata) are used to refer to the two main layers of the outer covering of the herring egg, because of unresolved problems associated with the origin and nomenclature of the envelope of teleost eggs (Anderson, 1967; Ginzburg, 1968).

* Prepared under the auspices of the German-Canadian Scientific and Technical Cooperation Agreement (Contribution No. 16). 
A number of subtle and suggested sublethal responses arising from exposure to cadmium have been noted in marine teleost eggs (Rosenthal \& Alderdice, 1976). These include a softening of the capsule during development of the egg of Atlantic herring Clupea barengus (Rosenthal \& Sperling, 1974; von Westernhagen et al., 1974), and of Baltic flounder, Pleuronectes flesus (von Westernhagen \& Dethlefsen, 1975). Cadmium was taken up rapidly by eggs incubated in cadmium solutions, although most of it was found in association with the outer covering of the egg rather than with the embryo or yolk sac (Rosenthal \& Sperling, 1974). It is assumed that cadmium ions attach to binding sites in the mucopolysaccharide "jelly coat" surrounding the herring egg capsule (Rosenthal \& Sperling, 1974). Furthermore, fragility of the envelope of eggs incubated in cadmium solutions suggests that cadmium also may be bound to the protein or polysaccharide (Ginzburg, 1968) components of the capsule itself.

Salinity of the incubation medium also influences the response of teleost eggs to cadmium exposure. Cadmium uptake of Atlantic herring eggs is increased substantially in lower salinities (von Westernhagen et al., 1974). Cadmium uptake in eggs of the Baltic flounder (von Westernhagen \& Dethlefsen, 1975) and marine garpike Belone belone (von Westernhagen et al., 1975) also is increased in lower salinities, but to a lesser extent. Detrimental effects of exposure to cadmium have been shown to increase in lower salinities for all three species (von Westernhagen et al., 1975). Their data show that more cadmium is taken up by eggs in higher cadmium concentrations, that these amounts approach asymptotic levels, and that these levels are highest in lower salinities. The latter observation suggests that there may be competition between $\mathrm{Ca}^{++}$and $\mathrm{Cd}^{++}$for binding sites in the jelly coat or the capsule of the egg. The lower calcium content of dilute sea water presumably would allow more $\mathrm{Cd}++$ to participate in binding or complexing with components of the two egg envelopes at higher equilibrium levels. It is assumed that changes in calcium-cadmium ratios also may have an important influence on hardening (Zotin, 1958) of the egg membrane, a process requiring calcium and inhibited by cadmium (Nakano, 1959).

This paper examines changes in bursting pressure, as a measure of capsule condition, of Pacific herring eggs incubated in cadmium-seawater solutions following fertilization in normal $(20 \% \mathrm{~S})$ sea water.

\section{MATERIALS AND METHODS}

Ripe adult herring were hand-selected for condition and ripeness from a trap net on Saltspring Island, Georgia Strait, British Columbia. They were transported in a 600-1 tank, cooled with ice, to the Biological Station, Nanaimo. There they were transferred to a circular tank ( $8-\mathrm{ft}$ diam, $2^{1 / 2}-\mathrm{ft}$ depth). Frozen marine plankton were offered to the fish within $24 \mathrm{hr}$ of the transfer; the food was readily accepted. and it was replaced gradually with fine "starter pellet" salmon feed until the fish were feeding on the pellets alone. Small numbers of herring then were segregated by sex, transferred to $780-1$ tanks in the laboratory, and used as required. The main 
stock of ripe herring provided fertile gametes for over 2 months, until water temperatures reached about $10^{\circ} \mathrm{C}$.

The eggs were applied in rows to $50 \times 75-\mathrm{mm}$ microscope slides, previously treated wtih a $1 \%$ solution of Siliclad to facilitate later removal of the adhesive eggs. Eggs were applied to slides singly by touching the genital papilla of the female quickly to the slide surface. The technique provided eggs with one contact plane, that on the glass surface, and avoided possible damage to the jelly coat that could occur in attempting to separate egg adhering to one another. The unfertilized egg samples so prepared were stored (Alderdice \& Velsen, 1978) in glass slide-staining carriers in $20 \% \mathrm{~S}$ sea water at $5{ }^{\circ} \mathrm{C}$. Storage time varied between 30 and $60 \mathrm{~min}$. When samples were complete, all were fertilized simultaneously in a dilution of $0.025 \mathrm{ml}$ herring milt per $100 \mathrm{ml} 20 \% \mathrm{~S}$ sea water at $5^{\circ} \mathrm{C}$. Ten minutes after fertilization the eggs were washed in $20 \% \mathrm{~S}$ sea water and moved to the test tanks. Test conditions were set up in $40-1$ tanks at $5{ }^{\circ} \mathrm{C}$, providing (a) 5,20 and $35 \% \mathrm{~S}$ sea water without cadmium, and (b) $20 \% \mathrm{~S}$ sea water with $0.05,0.1,1,5$, and $10 \mathrm{ppm} \mathrm{Cd}$. Cadmium solutions were prepared from anhydrous $\mathrm{CdCl}_{2}$ previously dried for $24 \mathrm{hr}$ at $60^{\circ} \mathrm{C}$.

Eggs were removed from the slides with an iris microscalpel, at intervals after fertilization and throughout the incubation period, care being taken not to damage the jelly coat. Bursting pressures were obtained for 10 eggs at each interval, daily until $375 \mathrm{hr}$ after fertilization and every second day thereafter until hatching. Bursting pressure was estimated by positioning each egg between two $1-\mathrm{cm}^{2}$ pieces of microscope slide on the top pan of a direct reading, tared $2000-\mathrm{g}$ balance. A micromanipulator mounted rigidly behind the balance pan positioned a probe on the upper glass plate immediately over the egg. Pressure was applied at rates of approximately $5 \mathrm{~g} / \mathrm{sec}$ for eggs with bursting pressures up to $100 \mathrm{~g}$, and $50 \mathrm{~g} / \mathrm{sec}$ for eggs with bursting pressures up to $1000 \mathrm{~g}$. At the bursting point the applied pressure ( \pm approx. $5 \%$ ) was recorded.

In some tests a few eggs within the first $24 \mathrm{hr}$ were flaccid and highly elastic. They could be flattened, without bursting, and were not recorded. From 24 hr onward there were a few instances where bursting pressures were greater than $2000 \mathrm{~g}$, the limit of the balance's registration. These values, recorded as $2000 \mathrm{~g}$, differed markedly from usual values and tended to distort computed mean bursting pressures. Calculation of median bursting pressures tended to minimize the effect of the outliers while at the same time stabilizing the variances. For graphic convenience, a logarithmic time scale also has been used to illustrate each bursting pressure series.

Ten egg diameters were also measured at each sampling interval in each of the three salinities and five cadmium concentrations. From these diameters, egg volumes were calculated. Herring eggs tend to be ellipsoidal. Two diameters can be seen in the plane of view under a microscope, one a minor $\left(d_{1}\right)$ and one a major $\left(d_{2}\right)$ diameter. Assuming that the minor diameter not measured $\left(d_{3}\right)$ - that vertical to the plane of view - is equal to $d_{1}$, then the volume of an egg

$$
\mathrm{V}=4 / 3 \pi\left[\left(1 / 2 \mathrm{~d}_{1}\right)^{2} \times\left(1 / 2 \mathrm{~d}_{2}\right)\right]
$$

Egg volumes were compared for the period between days 4 and 10 (at $5^{\circ} \mathrm{C}$ ) after 
fertilization, a period when egg volumes generally were found to be more constant (Alderdice et al., 1979).

\section{RESULTS}

\section{Effect of salinity}

Capsule strength. The time course of changes in bursting pressure in the three salinities (Fig. 1) includes a rise from fertilization to an initial maximum, a subsequent reduction until $150-250 \mathrm{hr}$ after fertilization, a period of stability or increase to a lower secondary maximum, and a final decrease just prior to and during hatching. In $20 \% \mathrm{~S}$ at $5{ }^{\circ} \mathrm{C}$, initial maximum bursting pressures were reached

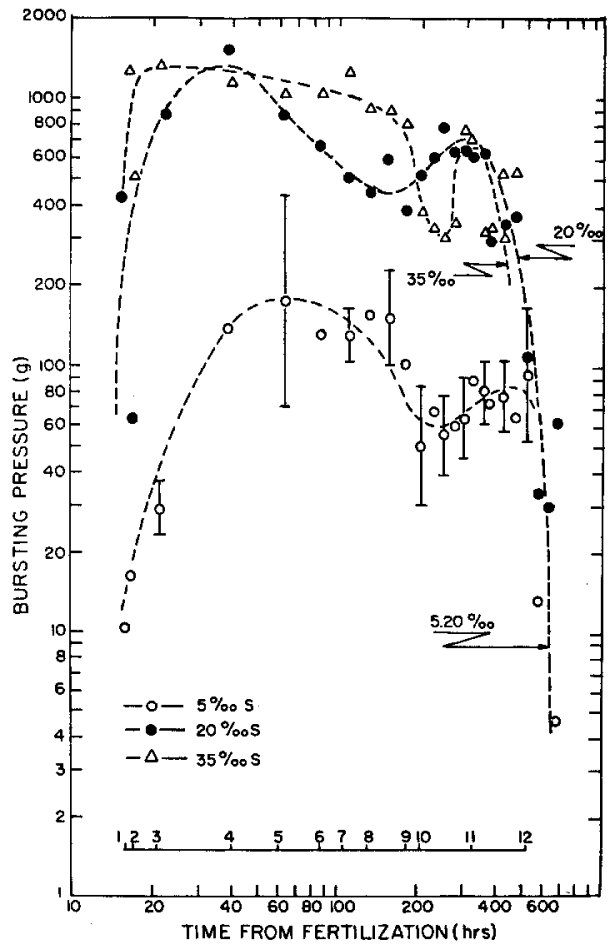

Fig. 1: Trends in change of bursting pressures of Pacific herring eggs fertilized in $20 \% \mathrm{~S}$ at $5^{\circ} \mathrm{C}$ and moved to incubation salinities of 5,20 , and $35 \%$ within $10-12 \mathrm{~min}$ after fertilization. Variability in bursting pressures within samples ( \pm 1 SD) is shown for the $20 \% \mathrm{~S}$ trend line. The scale in the lower part of the figure identifies observed stages of differentiation: 1--32-cell; 2--64-cell; 3--early blastodermal cap; 4--late blastodermal cap; 5--gastrula; 6--embryonic shield; 7--blastopore near closure; 8--blastopore closed, Kupffers vesicle prominent; 9--otic capsules evident; 10--embryo encircles yolk, heart beat, embryonic movement; 11--eye pigmentation beginning; 12--embryo two full circles around yolk 
in about $40 \mathrm{hr}$, when embryonic development had reached the late blastodermal cap stage. A following reduction in bursting pressures reached a minimum at approximately $150 \mathrm{hr}$, after the time of blastopore closure. The secondary, lesser rise in bursting pressure reached a maximum near $300 \mathrm{hr}$, just prior to the beginning of eye pigmentation and prior to the time when the hatching glands become prominent (360-400 hr). The final decrease in bursting pressure then began, culminating in initial hatches at $620 \mathrm{hr}$, and maximum hatching frequency near $690-700 \mathrm{hr}$.

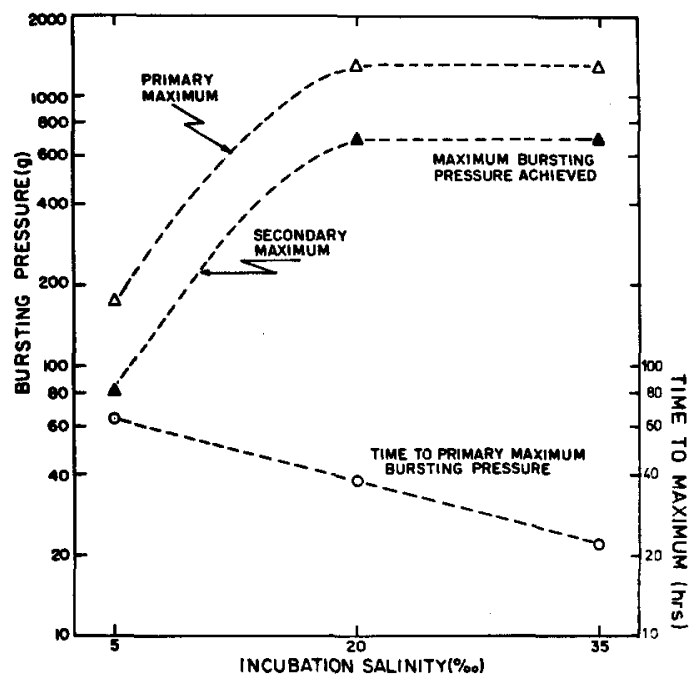

Fig. 2: Bursting pressures estimated for Pacific herring eggs at the primary and secondary bursting pressure maxima, and the time to development of maximum bursting pressures, in relation to incubation salinity

At $5 \% \mathrm{~S}$, development of bursting pressure maxima appeared to be delayed in comparison with timing of those events in $20 \% \mathrm{~S}$. The initial and secondary bursting pressure maxima occurred at approximately 60 and $450 \mathrm{hr}$, respectively.

At $35 \% \mathrm{~S}$, the initial bursting pressure maximum occurred approximately 20-25 hr after fertilization. The secondary maximum, if such exists, is not well defined. Assuming that the trend at 5 and $20 \%$ also applies at $35 \%$, then the secondary maximum would occur at approximately $300 \mathrm{hr}$.

In general, maximum bursting pressures were about $1300 \mathrm{~g}$, the minimum salinity for full development of bursting pressure being near or somewhat below $20 \%$ (Fig. 2). Bursting pressures achieved in the primary and secondary maxima follow similar courses with respect to incubation salinity. Rate of development of maximum bursting pressure increases with and appears to be a simple function of the incubation salinity.

Eg g volu me. Average egg volumes between days 4 and 10 of the incubation period were $1.466,1.384$, and $1.381 \mathrm{~mm}^{3}$ at 5,20 , and $35 \% \mathrm{~S}$, respectively. 
As might be expected, average egg diameters and volumes were greater in lower salinities.

Related observations. Between 16.0 and $17.5 \mathrm{hr}$ after fertilization (32- to 64-cell stage), the external jelly coat of eggs incubating in $5 \% \mathrm{~S}$ remained viscous, thick, and adhesive. In $20 \% \mathrm{~S}$ (64-cell stage) the jelly coat was thinner and harder. In $35 \% \mathrm{~S}$ (64-cell stage) the jelly coat was thin, hard, hyaline in appearance, and could be peeled away from the egg capsule.

A number of abnormalities were noted in eggs developing in $35 \% \mathrm{~S}$ sea water. Yolk diameters were noticeably smaller than those in $20 \% \mathrm{~S}$ at $255-376 \mathrm{hr}$. Retween 325 and $360 \mathrm{hr}$ the embryos were poor in appearance and the finfolds were crenulated. Body length of embryos in $35 \% \mathrm{~S}$ began to decrease about $424 \mathrm{hr}$ after fertilization, and episodes of embryonic mortality occurred around 279, 424 and $473 \mathrm{hr}$. In $35 \% \mathrm{~S}$, embryonic heart beat was slow and irregular, and body flexures $449 \mathrm{hr}$ after fertilization were limited to rapid, low amplitude movements resembling "shivering" (von Westernhagen et al., 1974). Initial hatching (and maximum hatching frequency) occurred at $570 \mathrm{hr}(660-700 \mathrm{hr})(5 \%), 619 \mathrm{hr}(690-700$ hr) $(20 \%)$, and $424 \mathrm{hr}(545-570 \mathrm{hr})(35 \% \mathrm{~S})$.

\section{Effect of cadmium}

Capsule strength. Bursting pressures of eggs fertilized in $20 \% \mathrm{~S}$ at $5^{\circ} \mathrm{C}$ and incubated in $0.05,0.1,1,5$, and $10 \mathrm{ppm} \mathrm{Cd}$ in $20 \% \mathrm{~S}$ sea water at $5^{\circ} \mathrm{C}$ are shown in Fig. 3. The time course of changes in bursting pressure follows the pattern for the salinity control (Fig. 1, 20\% S) in lower Cd concentrations ( 0.05 , $0.1 \mathrm{ppm})$, and the trends are modified in higher concentrations $(1,5,10 \mathrm{ppm})$. At progressively higher concentrations, cadmium appears to delay development of the primary bursting pressure maximum. The interval lengthened from $30-40 \mathrm{hr}$ after fertilization in the control (Fig. 1, 20\% S) and in 0.05 and $0.1 \mathrm{ppm} \mathrm{Cd} \mathrm{(Fig.} \mathrm{3),}$ to $40-50 \mathrm{hr}$ in $1 \mathrm{ppm}$, and to $80-90 \mathrm{hr}$ in $5 \mathrm{ppm}$. At $10 \mathrm{ppm} \mathrm{Cd}$ the primary maximum was eliminated, and bursting pressure continued to rise until the secondary maximum was reached $275-300 \mathrm{hr}$ after fertilization (Fig. 3). The relationship between bursting pressures achieved and cadmium concentration is more complex. Bursting pressures were greatest at the primary maximum for the control and for the 0.05 and $0.1 \mathrm{ppm} \mathrm{Cd}$ series. In the remaining higher cadmium concentrations $(1,5,10 \mathrm{ppm})$, highest bursting pressures were achieved at the secondary maximum. On the other hand, the magnitude of bursting pressures achieved at both primary and secondary maxima decreased precipitously to levels of 200-350 g with increasing cadmium concentrations to $1 \mathrm{ppm}$ (Fig. 4). The rise in bursting pressure in the $5 \mathrm{ppm} \mathrm{Cd}$ series (compared with 1 and $10 \mathrm{ppm}$ ) is considered anomalous, an assumption supported by further evidence in relation to egg volume (next section).

$\mathrm{Egg} \mathrm{volume.} \mathrm{Egg} \mathrm{volumes} \mathrm{were} \mathrm{relatively} \mathrm{constant} \mathrm{between} \mathrm{days} 4$ and 10 following fertilization. During that period measurement of eggs produced the following relation between cadmium concentration and egg volume $\left(\mathrm{mm}^{3}\right)$ : control (0 ppm Cd), 1.384; 0.05 ppm, 1.386; $0.1 \mathrm{ppm}, 1.331 ; 1 \mathrm{ppm}, 1.195 ; 5 \mathrm{ppm}, 1.302$; 


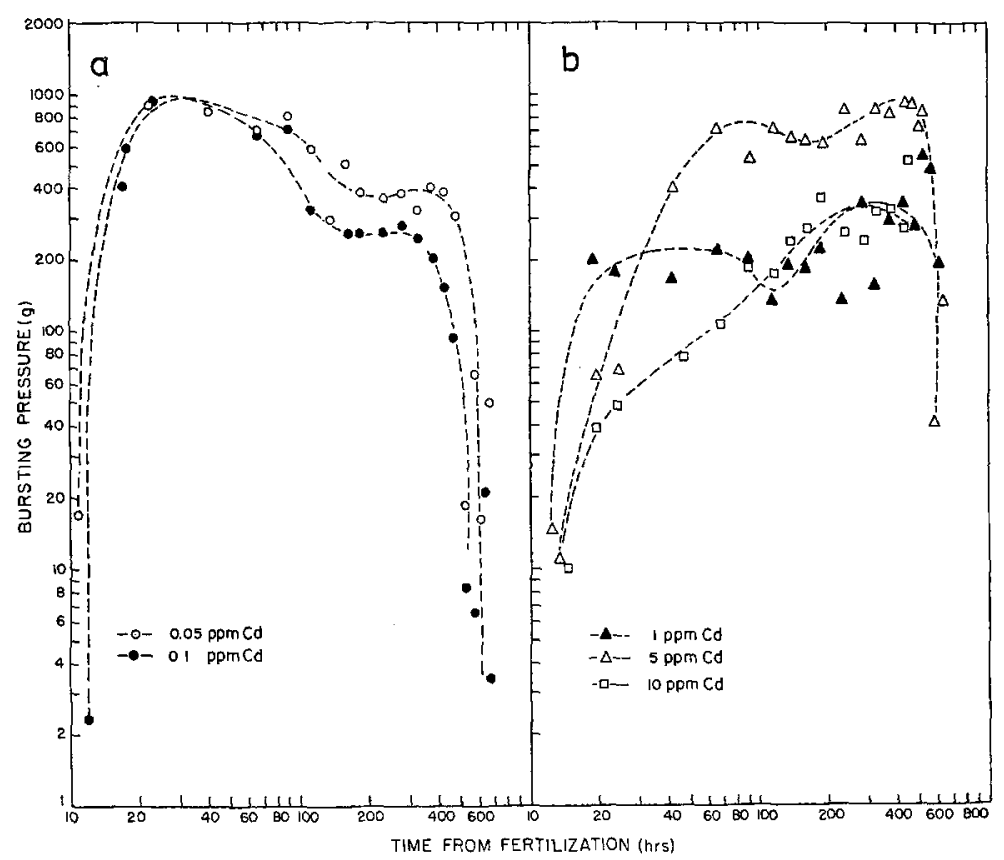

Fig. 3: Trends in change of bursting pressures of Pacific herring eggs fertilized in $20 \% \mathrm{~S}$ at $5{ }^{\circ} \mathrm{C}$ and moved $10-12 \mathrm{~min}$ after fertilization to $0.05,0.1,1,5$, and $10 \mathrm{ppm} \mathrm{Cd}$ in $20 \% \mathrm{~S}$ at $5^{\circ} \mathrm{C}$ for incubation. Scatter in the latter part of the 1 and $10 \mathrm{ppm} \mathrm{Cd}$ series is considerable, and the trends are open to interpretation

and $10 \mathrm{ppm}, 1.166 \mathrm{~mm}^{3}$. Again the data for the $5 \mathrm{ppm} \mathrm{Cd}$ series seem anomalous. Examination of all the egg volume data for each series from fertilization to hatching suggests that the eggs used in the $5 \mathrm{ppm} \mathrm{Cd}$ series were unusually large, leading to the interpretation that in this series both higher egg volumes and higher bursting pressures were atypical. Under that assumption, it appears that increases in cadmium concentration are associated with decreases in maximum bursting pressures and reduced egg volumes.

Related observations. Most ancillary observations were associated with events occurring in the $10 \mathrm{ppm} \mathrm{Cd}$ series. In that series, the shape of the blastodermal cap was unusual in comparison with the controls $17 \mathrm{hr}$ after fertilization (Rosenthal, personal communication). The external jelly coat also was less adhesive ( $33 \mathrm{hr}$ ). Epiboly was slightly more advanced $(79 \mathrm{hr})$ compared with that in the other cadmium concentrations, and that slight advance in development was maintained to the stage in which the tail bud of the embryo had lifted away from the yolk sac (200 hr). Embryonic abnormalities were first noted in the head region (127 hr). Embryonic activity decreased substantially between 320 and $345 \mathrm{hr}$. Shivering movements (von Westernhagen et al., 1974) replaced normal body flexures, as in the series incubated in $35 \% 0 \mathrm{~S}$ sea water, and swollen pericardia were noted as well as yolksac malformations. In $10 \mathrm{ppm} \mathrm{Cd}$, many embryos appeared to die just prior to hatching. Abnormal embryos also were detected at $378 \mathrm{hr}$ in both the 1 and $5 \mathrm{ppm}$ 


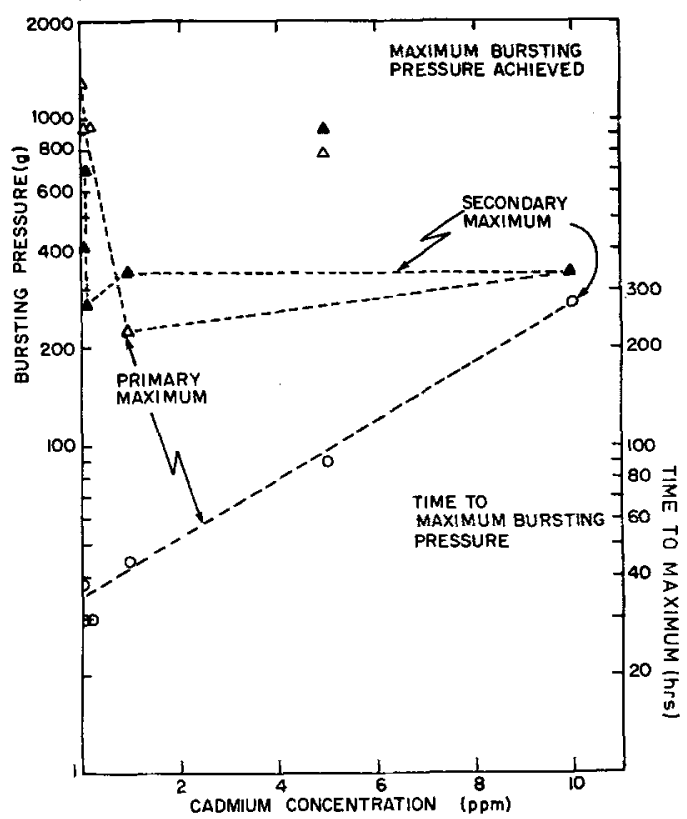

Fig. 4: Bursting pressures of Pacific herring eggs at the primary and secondary bursting pressure maxima, and time required to achieve the maxima, in relation to cadmium concentration at $20 \% \mathrm{~S}$ and $5{ }^{\circ} \mathrm{C}$. At $10 \mathrm{ppm} \mathrm{Cd}$ the primary maximum did not occur; bursting pressures continued to increase with time until the presumptive secondary maximum was reached. Maximum bursting pressures reached at $5 \mathrm{ppm} \mathrm{Cd}$ are considered anomalous and have been omitted in the suggested relationship (see text)

Cd test series. A brown discoloration of the jelly coat was observed in eggs exposed to the higher cadmium concentrations (in $1 \mathrm{ppm} \mathrm{Cd}$, after $202 \mathrm{hr} ; 5 \mathrm{ppm}, 60 \mathrm{hr}$; $10 \mathrm{ppm}, 40 \mathrm{hr}$ ).

Hatching distributions in the various cadmium concentrations were not obtained. However, the following relation was noted between cadmium concentration and incubation time (hours) to first hatch (and maximum hatching frequency): control, no cadmium, $619 \mathrm{hr}(690-700 \mathrm{hr}) ; 0.05 \mathrm{ppm}, 618 \mathrm{hr}(680-685 \mathrm{hr}) ; 0.1 \mathrm{ppm}, 618 \mathrm{hr}$ (680-685 hr); $1 \mathrm{ppm}, 523 \mathrm{hr}(630 \mathrm{hr}) ; 5 \mathrm{ppm}, 476 \mathrm{hr}(595 \mathrm{hr}) ;$ and $10 \mathrm{ppm}$, $429 \mathrm{hr}(450 \mathrm{hr})$.

\section{DISCUSSION}

Development of capsule strength in teleost eggs begins at fertilization. In the flaccid, unfertilized egg the peripheral cytoplasm lies in close proximity to the inner surface of the capsule. At fertilization, cortical alveoli in the cytoplasmic cortex rupture, their contents entering the presumptive perivitelline space (Nakano, 1969). The colloidal alveolar fluid contains organic substances, likely consisting of glycoproteins and lipoproteins (Eddy, 1974). These do not pass through the capsule, 
but cause water to be imbibed from the surrounding external medium. The colloids and the imbibed water mix to form the perivitelline fluid. The perivitelline fluid of the Pacific herring egg is detectable about $7 \mathrm{~min}$ after fertilization $\left(5^{\circ} \mathrm{C}\right.$ ); formation of the fluid is half completed in about $2^{1 / 4} \mathrm{hr}$ and complete in about 6-11 hr depending on the incubation salinity (Alderdice et al., 1979).

Associated with formation of the perivitelline space is a hardening of the egg capsule. Hardening of salmonid eggs is an irreversible process involving changes in properties of the capsule; the process requires calcium (Kusa, 1949) and is attributed to the presence of an enzyme (Zotin, 1958). Even in water-hardened eggs there is a substantial net transport of water across the capsule (Loeffler, 1971). In addition, a number of ions $\left(\mathrm{H}^{+}, \mathrm{Na}^{+}, \mathrm{K}^{+}, \mathrm{Cl}^{-}\right)$pass freely between the perivitelline fluid and the external medium (Shanklin, 1959; Kändler \& Tan, 1965 a).

Hence, following fertilization there is an increase in internal pressure as the flaccid egg imbibes water, swells, and become turgid. Loeffler's (1971) evidence of continuous exchange of water between the egg and the external medium implies, by analogy, that the egg resembles an inflated ball with microsieve walls. Internal pressure would be maintained through continuous "pumping" by the osmotic gradient associated with the perivitelline fluid colloid inclusions, which would tend to offset leakage of water and ions through the capsule. By inference from the various studies reported, herring eggs in sea water would set up an internal hydrostatic pressure, influenced by ionic and osmotic gradients, in which the internal turgor pressure would be balanced by the circumferential tension exerted by the elastic properties of the external envelope.

Eddy (1974) summarized these relations for an elastic sphere in equilibrium, whereby the internal pressure (P) of an egg is equal to the product of the tension ( $T$ ) exerted by the elastic forces of the outer envelope and a function of the radius, $2 / r$, so that $P=2 T / r$ (Burton, 1962). Thus a small egg can have a high internal pressure, which can be maintained by a low wall tension. Conversely, a larger egg with the same internal pressure would require a higher wall tension. In the present study, the external force applied to the egg would be transmitted internally to the whole capsule, increasing wall tension. With further increase in pressure, the elastic limit of the egg envelope eventually would be reached and the structure of the envelope would begin to lose its integrity. The bursting pressure is reached when the structure fails and the capsule ruptures. Therefore factors that will influence internal pressure, circumferential tension, or egg volume may influence bursting pressures.

The bursting pressure obtained show similar time trends and primary and secondary maxima as found for eggs of the plaice (Pleuronectes platessa) by Pommeranz (1974). Maximum bursting pressures of Pacific herring eggs (1300 g) compare with 400-700 g for the plaice (Pommeranz, 1974; Eddy, 1974), 3000-3500 g for the Atlantic salmon (Hayes, 1949) and 265-450 g for wild carp, Cyprinus carpio (Rubtsov, 1973). In general, bursting pressures of teleost eggs examined range from about 100 to $9000 \mathrm{~g}$ (Blaxter, 1969; p. 234).

Among marine fishes, egg diameters for a given species tend to be larger in lower salinities (Kändler and Tan, 1965b; Solemdal, 1967; Lönning and Solemdal, 
1972; May, 1974). Eggs of the Atlantic herring approach minimum diameters in salinities of 30-50\% (Holliday, 1965). Those of the white sea herring, C. b. pallasi, show a continuing decline in diameter in salinities from near 0 to $50 \%$ (Dushkina, 1973). The current results indicate that both egg volume and bursting pressure are influenced by incubation salinity and exposure to cadmium. The question arises as to whether the volume changes noted could account for the changes in bursting pressure observed. Bursting pressure, as measured, estimates the limiting circumferential tension on the egg envelope and that tension is a function of turgor pressure and egg size. It follows that a knowledge of bursting pressure-wall tension relations requires information on turgor pressure. To explore these relations, we incubated another set of eggs in 5, 20 and $35 \% \mathrm{~S}$ sea water at $5{ }^{\circ} \mathrm{C}$. Turgor pressures were examined with apparatus patterned after that of Gray (1932).

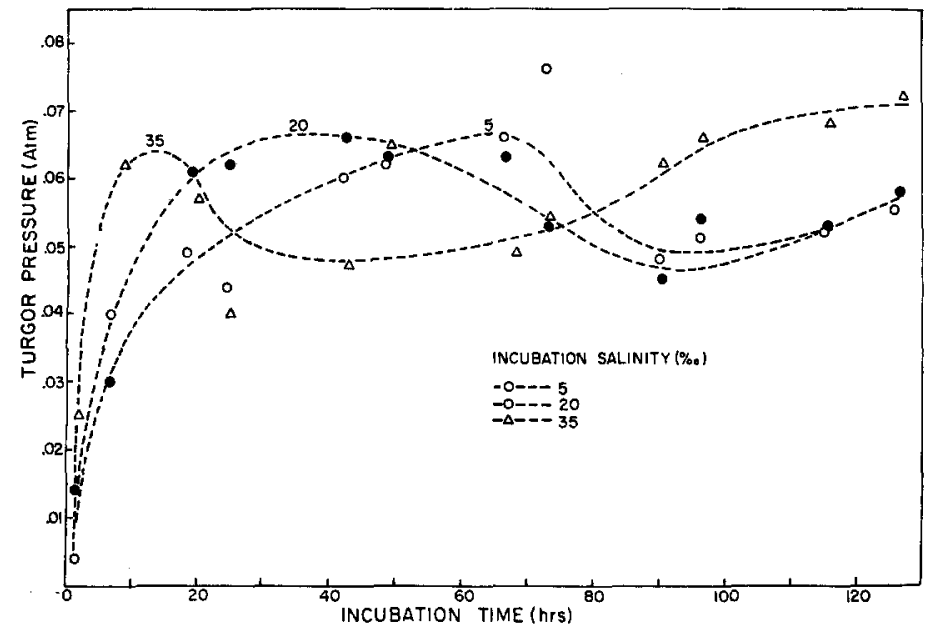

Fig. 5: Turgor pressure (atmospheres) of Pacific herring eggs incubated in 5, 20 and 35\% S sea water at $5{ }^{\circ} \mathrm{C}$. The trend lines are tentative

There is substantial variability in the data obtained (Fig. 5). However initial maximum turgor pressures appear to be achieved more rapidly in the higher salinities in a pattern similar to that for bursting pressure (Fig. 1). Also, turgor pressures of eggs in the three salinities vary approximately between 0.05 and 0.07 atmospheres, the average between 20 and $100 \mathrm{hr}$ being $0.057 \mathrm{~atm}(43.3 \mathrm{~mm} \mathrm{Hg}$ ), or about 57750 dynes $/ \mathrm{cm}^{2}$. Two estimates of circumferential tension then may be obtained: (a) that for the egg at rest, based on turgor pressure and size, and (b) the limiting tension, based on bursting pressure of the same eggs. These relations are summarized for the following examples (Table 1).

The anomalous results for the $5 \%(0 \mathrm{ppm} \mathrm{Cd})$ and $20 \%(10 \mathrm{ppm} \mathrm{Cd})$ incubations, where the limiting tensions are lower than would be expected on the basis of turgor pressure and size of the eggs, suggests that volume changes per se have only a small influence on bursting pressure. Therefore it is presumed that the 
Table 1

Influence of salinity and cadmium on egg volume and capsule strength in Pacific herring eggs.

Data based on turgor pressure and egg size as well as on bursting pressure

\begin{tabular}{|c|c|c|c|c|c|c|c|c|}
\hline $\begin{array}{r}\text { Incuba- } \\
\text { tion \%0 } \\
\text { (ppm Cd) } \\
\end{array}$ & $\begin{array}{c}\text { Mean egg } \\
\text { volume } \\
\left(\mathrm{mm}^{3}\right)\end{array}$ & $\begin{array}{l}\text { Radius* } \\
\text { (cm) }\end{array}$ & $\begin{array}{c}\text { Surface } \\
\text { area } \\
\left(\mathrm{cm}^{2}\right)\end{array}$ & $\begin{array}{c}\text { Tension } \\
(\text { dynes/ } \\
\mathrm{cm})\end{array}$ & $(\mathrm{g})^{\mathrm{B}}$ & $\begin{array}{c}\text { rsting Pre } \\
\left(\mathrm{g} / \mathrm{cm}^{2}\right)\end{array}$ & $\begin{array}{l}\text { ssure } \\
(\mathrm{mm} \mathrm{Hg})\end{array}$ & $\begin{array}{c}\text { Limiting } \\
\text { tension } \\
(\text { dyn } / \mathrm{cm})\end{array}$ \\
\hline $5(0)$ & 1.466 & 0.07 & 0.06 & 2035 & 175 & 10.9 & 8.0 & 396 \\
\hline $20(0)$ & 1.384 & 00 & & 199 & 1300 & 78. & 57. & 2644 \\
\hline $35(0)$ & 1.381 & 0.069 & 0.06 & 199 & 1300 & 80. & 57.3 & 2639 \\
\hline $20(10)$ & 1.166 & 0.0653 & 0.0536 & 1885 & 350 & 18.8 & 13.8 & 600 \\
\hline \multicolumn{9}{|c|}{ * Equivalent spherical radius } \\
\hline
\end{tabular}

influence of low salinity or exposure to cadmium may be expressed through changes occuring in the structure or integrity of the jelly coat or capsule themselves.

Dushkina (1973) noted that the jelly coat ("mucosa") of white sea herring eggs swells greatly in low salinities. Reduction of egg volume in higher salinities was a result partly of thinning of the jelly coat and partly of a decrease in the volume of the perivitelline fluid. Rubtsov (1973) removed the jelly coat from eggs of the wild carp (Cyprinus carpio) and compared capsule strength with that of normal eggs with the jelly coat intact. One day after fertilization, capsule strength of eggs without the jelly coat was about one-third lower than in the control. Therefore, the jelly coat appears to contribute to the bursting pressure of the whole egg. In the current study, a delayed thinning of the jelly coat was noted in the low salinity. Hence the delayed rise in bursting pressure and the lower bursting pressure maximum achieved in $5 \%$ could be attributed in part to a delayed hardening on the jelly coat.

A number of related observations suggest that the structure of either the jelly coat or capsule of marine teleost eggs may be altered by exposure to cadmium. Cadmium inhibits the hardening of the egg after fertilization, a process known to require calcium (Nakano, 1969). Eggs of the Baltic flounder (Pleuronectes flesus), incubated in cadmium-sea water after fertilization in uncontaminated water, developed weakened capsules subject to rupture (von Westernhagen \& Dethlefsen, 1975). Similar results were obtained by Rosenthal and Sperling (1974) and von Westernhagen et al. (1974) for eggs of Atlantic herring. In the current study Pacific herring eggs also showed weakened envelopes, particularly in $10 \mathrm{ppm} \mathrm{Cd}$. In general, investigations have shown cadmium to be confined largely to the outer covering of eggs exposed to cadmium (Rosenthal \& Sperling, 1974), with levels of contamination being reduced in higher salinities.

The fragility of the outer envelope of cadmium-contaminated eggs draws attention to the need to determine where these effects occur - in the capsule, the jelly coat, or in both. It is assumed that cadmium competes with calcium for binding sites in both the jelly coat and capsule of the egg (von Westernhagen et al., 1975). Cadmium would occupy those sites in relation to $\mathrm{Ca}^{++} / \mathrm{Cd}^{++}$ratios, determined by the cadmium concentration, the salinity of the medium, and its $\mathrm{pH}$. The 
latter could affect the specificity of the reaction of cadmium with various protein groups because of the different $\mathrm{pKs}$ of the latter (Madsen, 1963). Accumulation of cadmium and its toxicity appear related to the presence or absence and thickness of the jelly coat. The thick jelly coat of Atlantic herring eggs accumulates greater amounts of cadmium than the egg of Pleuronectes flesus (von Westernhagen \& Dethlefsen, 1974), which possesses a much thinner jelly coat. Cadmium also is more toxic to eggs of the latter species, even though the whole egg of Pleuronectes flesus accumulates less cadmium than the Atlantic herring egg.

Based on the current evidence, we suggest the following. Eggs possessing a thick jelly coat probably bind in the jelly coat a considerable proportion of the cadmium with which they come in contact. The amount bound likely will be influenced largely by the properties of the incubation medium. The bound cadmium would appear to alter the physical properties of the jelly coat whereby its contribution to the strength of the egg envelope is reduced. In addition, a small amount of cadmium evidently can penetrate the jelly coat and capsule. We suspect that cadmium also must occupy binding sites in the capsule itself, as egg volume is reduced in cadmium-contaminated sea water and there is an apparent loss of elasticity and tensile strength of the capsule.

Finally, the fragility of Pacific herring eggs exposed to very low salinities, or to cadmium-contaminated sea water, could increase the vulnerability of eggs to mechanical damage. For Pacific herring eggs this increase in vulnerability in low salinities would become evident in salinities somewhere below $20 \%$.

\section{ZUSAMMENFASSUNG}

Die Druckfestigkeit von Heringseiern erreicht nach der Befruchtung rasch erstes Maximum, fällt dann leicht $a b$ und steigt gegen Ende der Inkubationszeit erneut an. Kurz vor dem Schlupf sinkt die Druckfestigkeit erheblich. Hohe Salzgehalte beschleunigen das Erreichen des ersten Maximums (20-35\% S; $1300 \mathrm{~g}$ ). In 20\% S tritt es $40 \mathrm{~h}$ nach der Befruchtung ein, während es in $35 \% \mathrm{~S}$ schon nach $20-35 \mathrm{~h}$ beobachtet werden kann. In geringen Salzgehalten $(5 \%$ S) tritt das erste Maximum verzögert ein $(60 \mathrm{~h})$ und liegt bei mittleren Werten von nur $175 \mathrm{~g}$. Eidurchmesser und Eivolumen waren am größten in $5 \%$ S und lagen bei 20 und $23 \% \mathrm{~S}$ nahe den beobachteten Minima. Die Aushärtung der äußeren, klebrigen Eihülle war in geringen Salzgehalten verzögert. Auch die Inkubationszeit war durch den Salzgehalt beeinflußt. Sie war am längsten in $20 \% \mathrm{~S}(690-700 \mathrm{~h})$ und am kürzesten in 35\% S (545-570 h). Die Exposition der Heringseier gegenüber Cadmium veränderte alle beobachteten Parameter. In Abhängigkeit von der Cadmium-Konzentration verzögerte sich das Auftreten des ersten Druckfestigkeitsmaximums. Dieses war gleichzeitig erheblich kleiner: 200-350 g (1 ppm Cd) gegenüber $1300 \mathrm{~g}$ in den Kontrollen. Auch die Eivolumina nehmen mit steigender Cadmium-Konzentration ab.

Acknowledgement. The authors acknowledge and appreciate the assistance of their colleagues in this study, including Drs. T. R. Rao, H. von Westernhagen and Ms. M. Bell. 


\section{LITERATURE CITED}

Alderdice, D. F. \& Velsen, F. P. J. 1978. Effects of short-term storage of gametes on fertilization of Pacific herring eggs. Helgoländer wiss. Meeresunters. 31, 485-498.

- Rosenthal, H. \& Velsen, F. P. J. 1979. Influence of salinity and cadmium on the volume of Pacific herring eggs. Helgoländer wiss. Meeresunters. 32, 163-178.

Anderson, E., 1967. The formation of the primary envelope during oocyte differentiation in teleosts. J. Cell Biol 35, 193-212.

Blaxter, J. H. S., 1969. Development: eggs and larvae. In: Fish physiology. Ed. by W. S. Hoar \& D. J. Randall. Acad. Press, New York, 3, 177-252.

Burton, A. C., 1952. Physical principles of circulatory phenomena: the physical equilibria of the heart and blood vessels. In: Handbook of physiology. Section 2: Circulation. Ed. by W. F. Hamilton \& P. Dow. Am. Physiol. Soc., Washington, D. C., 1, 85-106.

Dushkina, L. A., 1973. Influence of salinity on eggs, sperm, and larvae of low-vertebral herring reproducing in the coastal waters of the Soviet Union. Mar. Biol. 19, 210-223.

Eddy, F. B., 1974. Osmotic properties of the perivitelline fluid and some properties of the chorion of Atlantic salmon eggs (Salmo salar). J. Zool. Lond. 174, 237-243.

Ginzburg, A. S., 1972. Fertilization in fishes and the problem of polyspermy. Israel Program for Scientific Translations, Jerusalem, $366 \mathrm{pp}$.

Gray, J., 1932. The osmotic properties of the eggs of the trout (Salmo fario). J. exp. Biol. 9, 277-299.

Hayes, F. R., 1949. The growth, general chemistry, and temperature relations of salmonid eggs. Q. Rev. Biol. 24, 281-308.

Holliday, F. G. T., 1965. Osmoregulation in marine teleost eggs and larvae. Calif. Coop. oceanic Fish. Invest. 10, 89-95.

Kändler, R. \& Tan, E. O., 1965a. Investigations of the osmoregulation in pelagic eggs of gadoid and flatfishes in the Baltic. I. Changes in volume and specific gravity at different salinities. C. M. - I. C. E. S. D 43.

- 1965b. Investigations of the osmoregulation in pelagic eggs of gadoid and flatfishes in the Baltic. II. Changes in chemical composition at different salinities. C. M. - I. C. E. S. D 44.

Kusa, M, 1949. Further notes on the hardening of the chorion of salmon eggs. Cytologia 15, $145-148$.

Loeffler, C. A., 1971. Water exchange in the pike egg. J. exp. Biol. 55, 797-811.

Lönning, S. \& Solemdal, P., 1972. The relation between thickness of chorion and specific gravity of eggs from Norwegian and Baltic flatfish populations. FiskDir. Skr. (Ser. Havunders.) 16, 77-88.

Madsen, N. B., 1963. Mercaptide-forming agents. In: Metabolic inhibitors. Ed. by R. M. Hochster \& J. H. Quastel. Acad. Press, New York, 2, 119-143.

May, R. C., 1974. Factors affecting buoyancy in the eggs of Bairdiella icistia (Pisces: Sciaenidae). Mar. Biol. 28, 55-59.

Nakano, E., 1969. Fertilization. In. Comparative morphology, biochemistry, and immunology. Ed. by C. B. Metz \& A. Monroy. Acad. Press, New York 2, 295-324.

Pommeranz, T., 1974. Resistance of plaice eggs to mechanical stress and light. In: The early life history of fish. Ed. by J. H. S. Blaxter. Springer, Berlin, 397-416.

Potts, W. T. W. \& Eddy, F. B., 1973. The permeability to water of the eggs of certain marine teleosts. J. comp. Physiol. 82, 305-315.

Rosenthal, H. \& Alderdice, D. F., 1976. Sublethal effects of environmental stressors, natural, and pollutional, on marine fish eggs and larvae. J. Fish. Res. Bd Can. 33, 2047-2065.

- \& Sperling, K.-R., 1974. Effects of cadmium on development and survival of herring eggs, p. 383-396. In: The early life history of fish. Ed. by J. H. S. Blaxter. Springer, Berlin, 383-396.

Rubtsov, V. V., 1973. The strength of the egg membranes and the volume of adhesive and nonadhesive eggs of wild carp and cultured carp [Cyprinus carpio (L.)] under different methods of incubation. J. Ichthyol. 13, 400-405. 
Shanklin, D. R., 1959. Studies on the Fundulus chorion. J. cell. comp. Physiol, 43, 1-11.

Solemdal, P., 1967. The effect of salinity on buoyancy, size, and development of flounder eggs. Sarsia 29, 431-442.

Westernhagen, H. von \& Dethlefsen, V., 1975. Combined effects of cadmium and salinity on development and survival of flounder eggs. J. mar. biol. Ass. U.K. 55, 945-957.

- \& Rosenthal, H., 1975. Combined effects of cadmium and salinity on development and survival of garpike eggs. Helgoländer wiss. Meeresunters. 27, 268-282.

- Rosenthal, H. \& Sperling, K.-R., 1974. Combined effects of cadmium and salinity on development and survival of herring eggs. Helgoländer wiss. Meeresunters. 26, 416-433.

Zotin, A. I., 1958. The membrane hardening enzyme of salmon eggs. Dokl. Akad. Nauk SSSR 121, 1105-1108. 